\title{
Reinsurance and Foreign Exchange Risk
}

\author{
by Henri Loubergé *
}

\section{Introduction}

When professional insurers discuss the economic difficulties that they have to face in their daily work, they will always give pride of place to the erratic fluctuation of exchange rates and the distortions caused by them with regard to technical results and profit and loss accounts.

This type of concern is felt particularly by reinsurance companies, mainly because they practice geographic dispersal of risks on an international scale, so that they deal in a large number of currencies (generally more than a hundred). Their total net assets expressed in national currency on the basis of assets and liabilities held in various currencies undergo substantial fluctuations owing to foreign exchange rate movements.

For reinsurance companies, as for all firms operating at the international level, the foreign exchange problem has become particularly acute since the adoption by major countries of the Western world of the system of floating rates of exchange. This is, first of all, because it is no longer a temporary problem due to the risk of devaluation or revaluation of an isolated currency, but rather a permanent concern. It is also due to the fact that the direction in which foreign currency rates will vary has become more difficult to forecast. The foreign exchange market being an efficient market in the financial sense of the word (see Fama [1970]), foreign exchange rates will at all times reflect the totality of the information available and will fluctuate in a random fashion as a function of the arrival of new information. Although there is always an underlying basic trend in their movements (as reflected by interest rate differentials), the direction of short-term fluctuations is difficult to predict ${ }^{1}$.

Unlike the conditions prevailing at the time of fixed (and nonetheless adjustable) exchange rates, speculation has become a dangerous game. In all the economic and financial circles concerned, it has given way to a careful management of the foreign exchange risk.

Compared with other operators in the international financial market, reinsurers encounter a certain number of specific problems in the management of foreign exchange risk. Essentially, these problems are linked with the random nature of the liabilities

* University of Geneva. This paper is based on the author's dissertation [1979]. The financial support of the Geneva Association is gratefully acknowledged. The author is also indebted to several European reinsurers for their helpful remarks and suggestions. None of them is however responsible for the views expressed or for any errors.

1 The attempts made to predict future foreign exchange rates with the help of econometric models (see Goodmann [1978]) have proved to be just as ineffectual for their intended purpose as the theory according to which the forward rate is an unbiased predictor of the future spot rate (Kohlhagen [1978], Solnik and Roll [1978]). 
accepted. This has led a number of authors, when dealing with the management of reinsurers' foreign exchange risk, largely to discard the procedures traditionally used in this field, in particular that of hedging in the futures market (see Grossmann [1974, 1977a]), and to recommend instead certain specific procedures or codes of conduct (see Lepine [1975] and Jannot [1975]).

The present paper purports to present a survey of this issue and to make a critical analysis of the many different opinions put forward in the matter. Since the first stage in the process of foreign exchange risk management is the identification of the risk, we shall deal with this aspect in the next section (section 2) taking as a point of departure the distinction- by now generally accepted - between accounting risk and economic risk. Section 3 will then deal with the procedures for the reduction and transfer of foreign exchange risk available to the reinsurer ; in particular, an assessment will be made therein of the merits of the proposed "basket of currencies" formula. In section 4, a comparison will be made between two possible policies : that of congruence on the one hand, which is favoured by many reinsurers, and, on the other hand, that of diversification of foreign exchange exposure, which is of a more general nature. Section 5 will set forth the main lessons to be drawn from the present study.

\section{The foreign exchange risk of reinsurers}

\subsection{Accounting exposure and economic exposure}

Foreign exchange exposure in a given currency is defined as the difference between the assets and the liabilities held in that currency. This difference (positive or negative) represents a net asset, the value of which, expressed in national currency, will fluctuate with the foreign exchange rates. If the values in the original currencies were alone relevant, this phenomenon would not constitute a source of concern : the foreign exchange risk would not exist. The conversion of the values in original currencies into national currency is, however, of vital importance for two reasons :

- firstly, because the assets expressed in national currency constitute the point of reference for the firm concerned; the firm in question has obviously spread its activities outside the territory of its country solely for the purpose of increasing its future profits as expressed in national currency ;

- second, because the firm must periodically exhibit the books of account and papers which reflect its activities and record the state of its assets ; now, in these documents, all the values are expressed in a single currency of account, which is generally the national currency.

The first of the above two reasons is the source of an economic risk; foreign exchange rate fluctuations will alter the prospective value of future profits. The second reason is the source of an accounting risk : the figures which go to make up the firm's image in the eyes of the outside world will suffer from foreign exchange rate fluctuations.

In a certain sense, the concept of economic risk is broader than that of accounting risk. This is firstly because the accounting risk relates to the exposure of the firm at a given moment, i.e. the moment when it is drawing up balance sheet, whereas the economic risk relates to the whole foreseeable future, to the developments in time of 
foreign exchange exposure and to the random distribution of future profits. Second, this is because the indirect effects of foreign exchange fluctuations must be taken into account and not only their direct effect on the books of account (e.g. one must endeavor to see whether the fall in value of an asset expressed in foreign currency will not be totally or partly off-set by better export results obtained by those branches whose currency of account has been devalued).

In another sense, however, it is a narrower concept because, from the economic point of view, one will only take into account those profits or losses which have already been made or those which are expected to emerge effectively. Those of a fictitious nature are ignored, since the conversion into the national currency of the elements concerned is not contemplated in a foreseeable future (e.g. tied-up funds of foreign branches, certain stocks of goods, etc.).

These differences explain why the distinction between accounting risk and economic risk has been given so much prominence in the recent literature on foreign exchange risk (Ensor and Antl [1979], Prindl [1976], Jacque [1978]), and why certain treasurers refuse to attach any importance to accounting exposure.

As a matter of fact, it is apparent that the two concepts cannot be entirely dissociated : the accounting risk has also a material influence on a firm's future profits since the trading reports which it publishes shape its image in the eyes of its creditors, shareholders and competitors. If, because of foreign exchange profits and losses, trading results appear volatile, the firm will seem a risky investment and risk-averse investors will tend to rule out its securities from their portfolios. Accordingly, for a firm operating at the international level, foreign exchange risk cannot, strictly speaking, be confined either to the accounting aspect or the economic aspect; in fact, both notions will have to be taken into consideration together.

\subsection{Accounting risk in a reinsurance company}

The accounting risk has two aspects. On the one hand, it is constituted by the risk of distortion in the pattern of trading results of the firm (profits, turnover). On the other hand, it is constituted by the risk that foreign exchange profits or losses will emerge when, for balance-sheet purposes, the various accounts in foreign currencies are converted into national currency ${ }^{2}$.

In principle, the total foreign exchange loss or profit recorded by any firm at the end of its financial year will depend upon two factors :

(1) the foreign exchange exposure at the beginning of the financial year, multiplied by the percentage fluctuation of the foreign exchange rate during the year; and

(2) the variations in this exposure, multiplied by the percentage fluctuation of the foreign exchange rate between the date of each variation and the date of the balance-sheet.

2 In order to convert their foreign currency holdings into national currency, reinsurers use the current rate method (see Carter and Rodriguez [1976 p. 197]) : all the assets and commitments in foreign currencies are uniformly converted at the same rate which is arbitrarily fixed at a level close to the one prevailing in the foreign exchange market at the end of the financial year. 
Thus, for a currency whose exchange rate at the end of the financial year is lower than all the levels reached during the year, we will have :

- a foreign exchange profit arising from a possible short exposure at the beginning of the financial year and from decreases in the exposure during the year ;

- a foreign exchange loss arising from a possible long exposure at the beginning of the year and from increases in the exposure during the year.

The position is the converse for a currency which attains its highest level at the end of the financial year.

An observation of the reinsurers' accounting practice, however, shows that most of them calculate their foreign exchange losses and profits in a slightly different manner. They make use of an "agio account" for each foreign currency to effect the transition from foreign currency accounting to national currency accounting. The entries made in this account can be divided into three groups :

(1) At the beginning of the financial year, the entry for the net foreign exchange exposure is made at the rate used for the previous year's balance-sheet.

(2) During the year, all entries made in respect of foreign exchange operations real or fictitious ${ }^{3}$ - are made at the current rate.

(3) At the end of the year, the balance shown in the foreign currency accounts is entered at the rate used for the balance-sheet, in order to draw up the balancesheet and the profit and loss account in national currency.

Over the financial year as a whole, those different entries cancel each other out in the foreign currency section of the agio account, since the balance carried forward at the end of the year is equal to the sum of the opening entries and the operations carried out during the year. The equivalent amounts in national currency, however, will show a net balance because different foreign exchange rates have been used in the course of the year. This balance represents the foreign exchange profit or loss made on the currency in question : a profit if the net foreign currency entries have been, on average, made at a more favourable exchange rate than that used for the balance-sheet, and a loss in the contrary case.

This procedure differs from a full foreign exchange profit and loss accounting system, since it excludes from the basis on which the accounting risk is assessed those foreign currency exposure fluctuations which do not involve the application of any exchange rate.

These variations are those which are balanced by other entries made within the accounts in the foreign currency concerned instead of those in the national currency or in another currency. For example, a rise in the dollar assets following the settlement of a reinsurance balance payable in dollars will not involve any entry in the agio account during the financial year nor, accordingly, any foreign exchange loss (or gain) regardless of any devaluation (or revaluation) of the dollar between the date of the operation and the end of the financial year.

3 The term "fictitious foreign exchange operations" must be understood as meaning operations which require the use of a foreign exchange rate, but which do not really involve an actual purchase or sale of foreign currency. One example is the payment in a single currency of a number of reinsurance balances expressed in various currencies. 
This is so because a profit and loss account is drawn up separately for each currency and converted into national currency on the date of the balance-sheet, along with the balances of debtor and creditor accounts. If, on the other hand, the results in foreign currencies were constantly consolidated in a national currency account throughout the year, there would be no such gap : the payment in dollars of a positive balance in dollars would involve an entry in the agio account for the United States currency. This entry (a debit in the bank account in dollars, a credit in the agio account in dollars) will make the operation appear as a purchase of dollars which from the economic standpoint - would be perfectly justified : the decision to allow assets in dollars to rise is equivalent to buying dollars.

This may be a source of error in the assessment of foreign exchange risk by a reinsurer concerned only with his accounting exposure ; since the independent fluctuations of his foreign exchange exposure do not produce accounting profits or loss on foreign exchange, he may have a tendency to ignore them. But this is, in practice, a minor problem. On the one hand, the conversion of the balances of the profit and loss accounts uniformly at the exchange rate of the balance-sheet meets a specific need : it enables the reinsurer to calculate the results obtained at the end of the financial year from the reinsurance treaties entered into by him, without the foreign exchange rate fluctuations becoming a source of distortion (see $X[1974$, pp. 26-27]). On the other hand, the financial management of the company must be clearly aware of the need to follow carefully all the fluctuations of its foreign exchange exposure. Even if some of them do not affect the profits and losses of the current financial year, they affect the opening balances of the following year and, consequently, the basis on which its foreign exchange risk is calculated. Beyond the purely accounting risk, they are a source of economic risk.

\subsection{Economic risk in a reinsurance company}

(a) Global exposure and the problem of the evaluation of total liabilities

The evaluation of the economic exposure requires sufficient information on the progress of the business in order to be able to include all significant data, even if this data is not shown in the accounts.

For this purpose, a reinsurer cannot merely take separately each of the reinsurance treaties which he has accepted and evaluate their contribution to his foreign exchange risk, for this contribution is totally unknown.

For example, in the case of a proportional reinsurance treaty, the reinsurer knows that this treaty will give rise to payments of reinsurance balances quarterly or halfyearly, but he will not know in advance the date of the payments 4 , or the total balance,

4 The reinsurance balance is reported by the ceding insurer only with a time-lag of several months from the date of the closing of the quarterly - or half-yearly - account. A further time-lag will then occur between the forwarding of the balance and the date of payment. This is in principle limited to two weeks but will generally extend much further since the debtor is apt to allow himself a time period for payment (which will be all the longer as interest rates are higher) in the hope of seeing his debt wiped out by the emergence of balances in the opposite direction from the other contracts entered into with the same company. 
or even whether it will be a credit or a debit balance. In practice, he can therefore only use the total assets and liabilities emerging from the overall acceptances and retrocessions for each foreign currency. The term " total liabilities" must be construed to mean not only the commitments shown in the accounts (premium and claims reserves, debts payable in current account) but also all the foreseeable payments to be made in a foreign currency. Similarly, the term "total assets" must be construed to mean not only the assets in foreign currencies which have already been entered in the accounts (financial investments, technical deposits, credit balances in current account), but also all foreign exchange receivable in the foreseeable future on the basis of the acceptance policy pursued and of the information received on the various reinsurance treaties.

Thus, when a reinsurer learns that a given branch in a particular country is experiencing a sudden rise in its total losses, he will be led to revaluate his foreign exchange exposure by revising upwards his estimate of his commitments expressed in the currency concerned. In the same way, when the press announces the occurrence of a large-scale disaster that will involve many cash losses ${ }^{5}$, he will adjust his foreign exchange exposure so as to take this information into account.

A reinsurer has, nevertheless, great difficulty in evaluating, even in a global way, his economic foreign exchange exposure. For it is not always possible to build up sufficiently broad and well-diversified portfolios of acceptances in each currency so as to make it possible to assess commitments in a precise manner. There remains, moreover, the risk of a difference emerging between their ex post value and their ex ante evaluation. This risk (the insurance risk) also exists for the ceding insurer but takes on a special importance in reinsurance because not only do the liabilities arise in a random fashion but the estimates made of their value leaves a great deal to be desired.

As it is, the direct insurer is kept continuously informed of all developments in his business, of the underwriting of new policies, of renewals of old contracts, of claims which arise and of reports of experts, and is therefore able to adjust his total liabilities in keeping with all this data. He can thus reduce the extent of his uncertainty.

The reinsurer, for his part, does not have these facilities. By accepting the reinsurance treaties offered by the ceding insurers, he participates in the latter's com-

5 Cash losses constitute advances which the reinsurer makes to the ceding insurer on the future payments of claims in respect of large-scale disasters which have recently taken place. Grossmann [1974] has pointed out that cash payments for claims constitute forward assets for the reinsurer since he will be credited for them in the next reinsurance balance. It would, however, be inaccurate to conclude therefrom that the reinsurer's foreign exchange exposure will thereby be affected. For when he receives notice of a claim for payment in cash, the rise in his forward foreign currency position is simultaneously offset by a fall in his spot holdings of foreign currency, since he makes a bank transfer to the account of the ceding insurer. Consequently, his overall foreign exchange exposure will remain unchanged; only the structure of his holdings in foreign currencies is modified. Thus, the effect on foreign exchange risk of cash losses is negligible, unless the reinsurer is short of liquid assets in the currency in question and the notice of the ceding insurer compels him to operate in the foreign exchange market at an unfavourable juncture. Even in this last case, he can, however, easily hedge this risk by borrowing foreign currencies - a step which has moreover the advantage of redressing the time structure of his foreign exchange exposure. 
mitments and finds himself saddled with derived liabilities the pattern of whose development will not be directly known to him. His only information on the subject will be that furnished to him by the ceding insurers. They, and only they, are in a position to determine the reserves to be made for current risks and outstanding claims. The rub is that the reinsurer will usually receive this data only once a year, at the time of portfolio withdrawals concomitant with the drawing up of the final reinsurance balance. He will thus be unaware during the whole year of the extent of his actual liabilities. When he receives the last reinsurance balance of the year, the estimates made by the ceding insurer as at 31 December come to his knowledge. Since, however, he receives this information late, and since his liabilities vary following the operations made by the ceding insurer, it will by then be utterly out of date. Thus, the reinsurer's uncertainty will constantly grow until he receives the next balance showing the portfolio withdrawals. Then the cycle starts all over again. (See X [1974, pp. 20-21].)

Now, it is clear that the problem of liabilities is of crucial importance for the study of reinsurers' foreign exchange risk. Without a knowledge of the liabilities, it is impossible to calculate the foreign exchange exposure; and without calculating that exposure, how can the foreign exchange risk be evaluated ?

Therefore, the implementation of a policy for managing foreign exchange risk in a reinsurance company requires, as a matter of priority, the solution of this problem, partially at least. Unless one wants to manage the accounting risk exclusively, the flow of data from ceding insurer to reinsurer concerning the position regarding technical reserves must be considerably expanded. There is no doubt that this will imply additional work for the ceding insurers; it must, however, be noted that the latter will also benefit indirectly from this work to the extent that they hold reinsurance portfolios. Moreover, it is a service rendered by one of the parties to the reinsurance treaty to the other ; now, in the business world, every service has its price or remuneration. It will then be for the reinsurer to judge whether the management of foreign exchange risk represents a major problem and whether he is prepared to invest in it his time and his resources. Moreover, the introduction of automatic data treatment equipment in insurance and reinsurance companies should make it possible to obtain this additional information at no great marginal cost.

In the absence of such a system, the solution would be to make greater use of the information sources which are already available. In point of fact, reinsurers do not entirely lack useful indications regarding development in the business of their ceding insurers. The employees of the reinsurance company who travel all over the world to negociate the terms of reinsurance treaties with the ceding insurers invariably return with valuable information on this subject. The reinsurer is thus able to form an opinion - albeit a rather vague one - of the course taken by events in the direct insurance market. He can thus have a slightly better idea of where he stands as far as commitments are concerned and a less uncertain picture of the direction, perhaps even of the total amount, of the forthcoming reinsurance balances.

For the time being, the gathering of this information is simply a by-product of another activity, which is rightly considered more fundamental. However, the concern shown by reinsurers for problems of foreign exchange fluctuations and the necessity to ascertain their exposure in foreign currency as a preliminary step to any rational 
foreign exchange risk management, may induce them to consider what steps they can take in order to ensure that the numerous personal contacts with the ceding insurers are also used to ensure a better identification of the company's liabilities.

(b) Reinsurance in the currency of a third country

Most of the time, reinsurance treaties are made out in the same currency as the direct insurance transactions to which they relate (reinsurance in original currency). However, this practice has not always been the rule : before the Second World War, it was customary for a ceding insurer to reinsure systematically in his national currency, even when his direct transactions were carried out in foreign currencies ${ }^{6}$. And, to this day, this rule is still subject to many exceptions : reinsurance in the currency of a third country is frequently used to group together under one reinsurance treaty, direct insurance transactions of the same kind, but expressed in different currencies.

For example, a marine insurance company which covers risks in many different parts of the world may find it convenient to reinsure in one single currency (its national currency or an international currency such as the dollar). Alternatively, it can choose to conclude a reinsurance treaty the accounts of which are expressed in the various original currencies but in respect of which one single currency is used for payment purposes.

In the first case as in the second, the reinsurer accepts commitments expressed in a currency different from the original currency and can rightly question whether the principle whereby the reinsurer follows the fate of the ceding insurer is being respected (see Grossmann [1974]). Is he not made to run an additional foreign exchange risk? Will the profits and losses under the reinsurance treaties be affected by the fluctuations of the foreign exchange rate?

To answer these questions let us take the case of a reinsurer from a country $A$ (currency : the franc) who accepts a reinsurance treaty in dollars from ceding insurer in a country $B$ and relating to direct insurance transactions expressed in pounds sterling. Let us also assume, for the sake of simplicity, that the reinsurer can foresee, with sufficient accuracy, the liabilities which will flow from each of the transactions he accepts to reinsure.

During the year $n$, the ceding insurer has submitted two statements of account, one for the period $t$ during which the sterling rate was $£ 1 .-=\$ 2$. - and the other for the period $t+1$ when the rate of the pound has fallen to $£ 1 .-=\$ 1.50$. Each one of these two statements is made out both in the original currency (sterling) and in the currency of payment (dollar).

$\begin{array}{lcc}\text { Statement for period } t & \begin{array}{c}\text { Balance in } \\ \text { Original Currency }(£)\end{array} & \begin{array}{c}\text { Balance in } \\ \text { Currency of Payment (\$) }\end{array} \\ (£ 1 .-=\$ 2 .-) & +100 & +200 \\ \begin{array}{l}\text { Statement for period } t+1 \\ (£ 1 .-=\$ 1.50)\end{array} & -100 & -150 \\ \text { Profit or loss for the year } n & 0 & +50\end{array}$

6 E.g. See Schönenberger [1956] and Vukailovic [1958, p. 72]. 
The balances in the above table can be interpreted in several different ways. If the case is one of non-proportional reinsurance (excess of loss), the first figure may be taken to correspond to the premium payment and the second to the total amount of claims for losses or to the reserve for outstanding claims. If, on the other hand, it is a case of proportional reinsurance, these figures can be considered as constituting the two reinsurance balances which the ceding insurer has submitted to his reinsurer for the year $n$. Lastly, if the case is one of retrocession, they can be interpreted as the retrocession accounts submitted to a dollar pool in respect of transactions in sterling.

In any case, a study of this table enables us to make two series of interesting observations regarding the question under review.

Firstly, the fact that a reinsurance treaty is drawn up in the currency of a third country is a source of distortions in the technical results. In the above table, the profits and losses of the financial year balance in the original currency whereas there is a positive balance in the currency of payment. This is not unduly serious when, as in this case, a clear distinction is made between the currency of account and the currency of payment. If, however, the reinsurer receives only a statement of account in dollars, he will be unable to realize that the technical profit is purely of foreign exchange origin and he might wrongly attribute it to the diligence shown by the ceding insurer in conducting his business.

Second, reinsurance in the currency of a third country increases the foreign exchange risk because the profitability of the insurance transactions accepted will be affected not only by the fluctuations in the exchange rate for that currency, but also by the fluctuations in the exchange rates of the original currencies. Thus, in the above example, it will be noted that the reinsurer can show a foreign exchange profit on the reinsurance treaty expressed in dollars, even if the dollar rate in terms of national currency has not varied.

More generally, it is possible to draw the following distinction between reinsurance in original currency and reinsurance in the currency of a third country :

- The reinsurer of a country $\mathbf{A}$ who accepts treaties expressed in dollars concerning direct insurance transactions expressed in dollars will run a risk arising from fluctuations in the dollar parity. When the dollar rate changes, the value expressed in national currency of all the assets and liabilities in dollars will vary proportionally.

- The same reinsurer who accepts treaties in dollars concerning direct insurance transactions expressed in a variety of currencies will also run a foreign exchange risk in dollars. But this risk is compounded by the risk of fluctuations in the parities for the original currencies. Every time the external value of one of these currencies rises of falls in terms of the dollar, this will bring about a change in the nominal value of the liabilities and future receipts in dollars. For example, if the original currency is the pound sterling, a drop in value of sterling will cause a decrease in value of all future receipts and all liabilities expressed in dollars ; conversely, a rise in value of sterling will bring about their increase.

When the rate for the dollar is stable in terms of the national currency, these fluctuations in value will affect, without any other changes, all values expressed in national currency. However, if all the exchange rates vary, any fluctuations in the parities for the original currencies and the dollar can either offset one another or add 
up. Since the risk is measured by the dispersal of prospective profits and losses, the conclusion can be drawn that reinsurance in the currency of a third country actually increases the foreign exchange risk ${ }^{7}$.

There is a third source of distortion which does not appear in the example shown above. It concerns non-proportional reinsurance and more precisely the retention (or priority) limits of the ceding insurer. Let us take the example of an excess of loss treaty expressed in dollars in which the retention limit has been fixed at $\$ 15,000$. - . This treaty covers original insurance transactions in sterling. At the rate of $£ 1 .-=\$ 2$. prevailing during the period $t$, the ceding insurer will bear all losses smaller than or equal to $£ 7,500$. - and the reinsurer will participate in the excess of all other losses.

At $t+1$, the rate for sterling falls to $£ 1 .-=\$ 1.50$. From then on, only losses greater than $£ 10,000$. - exceed the retention limit specified in dollars. An upward revaluation of that retention limit has thus taken place de facto and will make the ceding insurer bear entirely all losses lying between $£ 7,500$ - - and $£ 10,000$. - As a result of the foreign exchange rate fluctuations, the reinsurance treaty has become more favourable for the reinsurer. Nevertheless, a rise in the parity for sterling rate would of course have produced the opposite result.

Another disadvantage of reinsurance in the currency of a third country is exposed in the work by Carter [1979]. This author points out that this practice gives a onesided advantage to the ceding insurer in so far as it is the latter who draws up the reinsurance balances and who consequently chooses the exchange rates for the conversion of the original currencies into the currency of payment.

As already stressed, there is a considerable time-lag between the date of closure of a proportional reinsurance account and the date on which this account is furnished to the reinsurer. Throughout this whole period, foreign exchange rates fluctuation and the value of the balance can therefore be considerably affected by the conversion rates used. If the balance is favourable to the ceding insurer, he will find it advantageous to use the parities prevailing at the time when the currency of payment was at its lowest level and the opposite occurs if the balance is favourable to the reinsurer. For the reinsurer, this situation is all the more uncomfortable as the number of original currencies is greater, so that there are more currencies with which the ceding insurer can play on the exchange rates. In order to protect himself against these types of distortion, he will usually take precautions at the outset of the signing of the reinsurance treaty. Instead of allowing the ceding insurer complete freedom to choose the conversion rates, he will agree with him on the use of the parities prevailing on a specified date, generally the date on which the accounts are closed. In this way, a possible source of conflict between the parties to the treaty is eliminated.

In practice, it is actually not uncommon for similar agreements to be adopted by ceding insurer and reinsurer in order to avoid the other drawbacks of reinsurance in the currency of a third country. As far as excess of loss reinsurance is concerned, it

7 It should be noted on this point that if the reinsurance balances are established in the currency of payment, the reinsurer cannot see the effect of variations in the exchange rates of the original currencies and no additional accounting risk will appear, even though an economic risk does exist. 
may thus be stipulated that the foreign exchange rate that will apply for the evaluation of the retention limit will be that prevailing on the day of signing of the treaty. In the same way, in the case of a retrocession, the payment made to the pool of the accepted reinsurance shares can be uniformly carried out at the end of the year, either at the foreign exchange rate used for the balance sheet, or at a rate which reflects the average of the rates prevailing during the year. ${ }^{8}$

Thus, the parallelism between reinsurance transactions and the corresponding retrocessions is maintained ${ }^{9}$. A well-balanced reinsurance treaty will produce a wellbalanced retrocession result; a profitable treaty will yield a positive result and an unprofitable treaty a negative result.

As a general rule, the best way of eliminating the distortions introduced by reinsurance in the currency of a third country is still, of course, the resort to reinsurance in original currency. As pointed out above, it is actually the most commonly used formula today (although perhaps not for the retrocession pools). It undoubtedly gives additional work to the ceding insurers, but the latter readily accept this since they, too, are exposed to the distortions introduced by reinsurance in the currency of a third country.

For indeed, when a ceding insurer makes transactions in foreign currencies and reinsures them in national currency, he covers liabilities in foreign currencies by means of forward assets in national currency, which puts him in a position of foreign exchange exposure.

In order to make this point more convincing, let us use once more the example given in the above table and let us assume, in order to simplify matters and to emphasize the influence of foreign exchange, that the ceding insurer from a country $B$ concludes transactions in sterling and reinsures them at $100 \%$ in dollars (the national currency). When he receives $£ 100$.- in premiums, creating a commitment in sterling of the same amount, he pays his reinsurer $\$ 200 .-$ (at the rate of $£ 1 .-=\$ 2 .-$ ) and records a forward asset, which is shown in the books as $\$ 200$. - , but which is in fact of uncertain value. Everything happens as if he had sold spot dollars against sterling and bought them back forward at an unspecified rate. The transaction is comparable to an arbitrage operation on sterling. If the pound sterling falls in value, the ceding insurer will undergo a foreign exchange loss. In the table above, this loss is materialised by the fact that he pays $\$ 50$. - on the whole of the reinsurance treaty whereas the original transactions in pounds show a balanced result ${ }^{10}$. This loss

8 It should be noted that if the retrocession is carried out at an average rate for the year, there results for the accepting reinsurer an accounting exposure which disappears when the retrocession is carried out at the rate used for the balance sheet.

9 On this point, see $X$ [1975].

10 This risk is not peculiar to the direct insurer. The reinsurer who retrocedes in national currency original transactions in foreign currencies is exposed to a similar risk. Even if he enters the retrocession in his accounts at the exchange rate used for the balance sheet and thereby eliminates the accounting foreign exchange risk for the current financial year, his liability in original currency will still be hedged in the pool by forward transactions in national currency, the value of which will be uncertain since it depends, in the last resort, on the foreign exchange rate prevailing when the outstanding claims are paid. 
could have been avoided if the ceding insurer had chosen to reinsure in original currency instead of national currency.

We will now conclude these comments on the economic risk of the reinsurer with some brief remarks on the position of British reinsurance companies. As a matter of fact, their problem has some analogy with the situation just described.

In the United Kingdom, there are many small reinsurance companies (apart from Lloyd's underwriters) who get their business through reinsurance brokers. Traditionally, the transactions between the brokers and these companies are carried out in sterling, whereas the brokers deal in foreign currencies with the foreign ceding insurers. At the time when sterling was a strong currency, or at least a stable one, this did not involve any drawback for the reinsurers; besides, this system had the advantage of simplifying the brokers' task : they could draw up all the reinsurance accounts in a single currency, instead of drawing up a large number of accounts in the various original currencies ${ }^{11}$. Today, this advantage still exists for the brokers, but the weakness of sterling has shown that the system can also be very disadvantageous to reinsurers. In non-proportional reinsurance, where there is a time-lag between the collection of the premium and the payment of claims, the reinsurer must pay the claims in an appreciated original currency although he has previously received the premiums in sterling. This will make him sustain considerable foreign exchange losses and will cause no less considerable distortions in the technical results.

One way of remedying this drawback would be for the reinsurers to invest their premium receipts in foreign currencies. They could thus hedge their commitments, whose value is tied to the foreign exchange rate. Unfortunately for them, this elementary method of foreign exchange management is forbidden by the Bank of England. Until a recent date, reinsurers were not authorized to purchase foreign currencies for investment purposes and, although this rule has now been somewhat relaxed, they still cannot, even today, invest in foreign currencies more than $75 \%$ of the total premiums collected by them in sterling in respect of original transactions in foreign currencies $\mathbf{1 2}$. And, notwithstanding the complaints of the reinsurers, the brokers do not seem to be willing to replace the traditional system of reinsurance in original currency ${ }^{13}$.

As a result, the small British reinsurance companies find themselves in a situation comparable to that of an insurer who systematically reinsures in national currency. Everything happens as though they sold foreign currencies spot for pounds sterling in order to buy them back later at an uncertain rate. The system compels them to speculate on the rise of sterling. This makes them run an economic risk which is difficult to manage otherwise than by increasing reinsurance premiums.*

11 In practice, in addition to the pound sterling, the US dollar and the Canadian dollar are sometimes also used in the relations between brokers and reinsurers.

12 Even when a reinsurer receives directly the premiums in foreign currencies, he must convert at least $25 \%$ of them into sterling.

13 The foreign exchange problems specific to reinsurance in the London market are very clearly explained in the article by Westby [1977].

* The situation presented here does not take into account the recent British decision to abolish all controls on capital movements. 


\section{Forelgn exchange procedures in a relnsurance company}

Once the accounting or economic foreign exchange exposure has been identified, it becomes necessary to define a goal and select the instruments of foreign exchange risk management which will make it possible to reach that goal at the lowest possible cost. In reinsurance, as in other activities, the main problem in this connexion is that of choosing the maximum acceptable risk : must the goal be the total elimination of the foreign exchange risk? And, if not, how far can one go ? This essential question will be the subject-matter of section 4 . First, however, it is necessary to consider the existing procedures for the reduction and transfer of the foreign exchange risk that are available to the reinsurer, giving special attention to the system of the "basket of currencies", the advantages of which have been often stressed.

\subsection{Procedures of foreign exchange risk management available to the reinsurer}

In the first place, we must point out that there is one aspect of the accounting risk which cannot be readily made the subject of a specific management policy on the part of the reinsurer. This is the influence of foreign exchange rate fluctuations on movements in business turnover and in book profits. In order to prevent the fall of acceptance currencies from having a negative impact on the results, the reinsurer would have to confine his operations to transactions in national currency or in a strong currency. This would mean a limitation in the geographical range of acceptances (all the more so if the national currency happens to be a strong one) or expressing all reinsurance treaties either in national currency or in a stable currency, regardless of the origin of the transactions concerned. The geographical dispersal of risks which is imperative cannot be reconciled with the first of these solutions. As for the second solution, it harks back to the system of reinsurance in the currency of a third country, the disadvantages of which have already been stressed.

In short, the reinsurer must resign himself to seeing the foreign exchange rate fluctuations introduce distortions in the movements of his turnover and his profits. All he can do is to reduce their economic impact by means of appropriate comments made at the time of publication of the company's annual report 14 .

Fortunately, the reinsurer is not as helpless when he has to cope with accounting and economic foreign exchange profits and losses. Most of the existing procedures for the reduction and transfer of foreign exchange risk can then be used with profit.

Among the procedures which are not suited to the needs of reinsurers, we find first those which are specially designed for exporters of goods and services : discount of bills, factoring and insurance of foreign exchange risk. There is also the procedure of selection of currency for financing purposes, which plays an important part in the

14 A recent article by Grossmann [1979] suggests that these distortions can be lessened by bringing back all the figures to one basic year and using the foreign exchange rate prevailing at that time. This suggestion seems interesting and deserves careful study. It raises, however, the question of the choice of a year of stability. The date proposed (1971) is unsuitable because, as subsequent developments have shown, the array of parities adopted in the Smithsonian Institute Agreements was highly unrealistic. 
activities of multinational companies but which is not of any great interest to reinsurers because the latter seldom need to ask for any outside financing. Lastly, and chiefly, there is the procedure of billing in national currency, which is very popular among industrial and commercial firms, but which reinsurers cannot employ because it would mean for them going back to the practice of reinsurance in the currency of a third country; the assets and liabilities in foreign currency would disappear but this would not prevent liabilities and future receipts from fluctuating in line with the exchange rates of the original currencies.

In principle, and if one ignores for the time being exchange control restrictions on capital movements, all the other procedures of foreign exchange risk management are suitable for the reinsurer. This latter can seek to offset possible foreign exchange losses by raising his premiums (Coppola [1974]) ; he can also adjust his foreign exchange exposures by operating in the spot market or in the futures market, by playing on the maturity dates for payment and on financial investments, or even by making his acceptance policy subject to constraints relating to the foreign exchange risk.

The well-informed reader will no doubt be surprised to see the futures market mentioned here among the arsenal of possible solutions. As a matter of fact, most of the writers who have studied the foreign exchange risk of reinsurers state that forward hedging is not a procedure adapted to the specific needs of reinsurers (see for example Grossmann [1977b] and Sonnenholzner [1975]). Their arguments are based on the random nature of the reinsurer's liabilities : since neither the date nor the total amount of these liabilities is known, it is not possible to hedge for them by means of a futures contract. This remark is, of course, not wrong but it is redundant. As it happens, the reinsurer does not have to operate in the futures market in order to hedge against his risk arising from a particular treaty, but needs it in order to cover the overall foreign exchange risk arising from his exposure in foreign currencies (Jannot [1975, p. 14]). If, for any reason, he finds himself too "long" in a particular currency, he can adjust his foreign exchange exposure by selling that currency forward. Hedging through the futures market cannot therefore be ruled out from the list of possible procedures ${ }^{15}$.

\subsection{Baskets of currencies}

"Currency baskets" are units of account constructed by combining the currencies of a number of countries. The best known are the Special Drawing Rights (SDRs) created under the auspices of the International Monetary Fund (IMF) ${ }^{16}$ and the

15 It should be noted, moreover, that reinsurers can avail themselves of the existence of optional futures contracts (see Prindl [1976, p. 74]). This type of contract comports a choice between two pre-established dates for the delivery of the currency promised under the futures contract: it can then serve as a hedge for debts receivable or debts payable which are expressed in foreign currency but the maturity date of which is uncertain. For the operator the drawback of this procedure is however that he is charged a forward rate which is selected by choosing, out of the two possible delivery dates, the date more advantageous to the bank.

16 The SDRs have constituted a currency basket only since 1 July 1974 . From their creation in 1970 and until that date, the value of SDRs was fixed in terms of gold. 
European Currency Unit (ECU), grouping the nine member countries of the European Economic Community (Common Market). These two units are mainly intended for use as reserve assets by central banks, but there exist others, more specifically intended for private users, as for example the Eurco, sponsored by a European bank consortium, or the B-Unit, devised by a British bank and based on the five currencies most commonly used in international trade, in equal shares.

The advantage of currency baskets lies in their comparative stability. Their value is not fixed, since it depends on the fluctuations of the exchange rates of the currencies involved ; but it is not very volatile since there are offsetting effects within each basket.

The banks which have sponsored their introduction in the business world have tried to make use of this advantage, especially with regard to long-term operations, which are difficult to hedge in the futures market : debenture loans, certain commercial contracts, etc.

In reinsurance matters, the use of currency baskets has been suggested on numerous occasions during the past few years ${ }^{17}$. They have been presented as a remedy to the foreign exchange problems of reinsurers :

(1) as units of account for the payment of premiums, claims and reinsurance balances and for the fixing of priorities ;

(2) as investment tools from which British reinsurers, in particular, might derive some profit since they collect their premiums in pounds sterling and have to settle claims in foreign currencies.

This second proposal is attractive in so far as it might contribute to lessen the difficulties which British reinsurers experience when trying to work out a foreign exchange risk management policy (see above p. 31). It would, however, be simpler and more rational for these reinsurers to be simply authorized to cover their liabilities in a foreign currency by making investments in that same foreign currency. This is no doubt the reason for the little response it has elicited until now.

As for the first proposal, it is in our opinion unacceptable for a number of reasons.

The first argument is based on the fact that the adoption of this system would result in a substantial increase in administrative work, because the value of the currency basket in terms of the various currencies used by the reinsurer would have to be evaluated anew every day. The use of a unit of account is understandable for such operations as debenture loans, because they are one-time operations which do not require a frequent evaluation of the value of the currency basket. The position is quite different, however, where a large number of operations in units of account have to be carried out daily.

A second reason for which this formula has little chance of seeing the light of day is that it would involve the same drawbacks as reinsurance in the currency of a third country. Since the direct insurance business would continue to be conducted in original currencies, drawing up the reinsurance treaties in a floating unit of account would have the same effects (distortion of technical results and increased foreign exchange risk) as reinsurance in the currency of a third country.

17 See for example the position of Lepine [1975]. 
Paradoxically, however, the most decisive argument is based on what is generally presented as the advantage of the system. The proponents of currency baskets argue that this procedure makes it possible to lessen the foreign exchange risk by sharing the burden of that risk among both parties to the transaction instead of leaving it entirely to one of them. They forget, however, in the first place, that the choice of the currency is part and parcel of the negotiations which precede the conclusion of a contract. It is rather unlikely that a company which is in a position to impose its choice in this matter will renounce that privilege without compensation. Thus, in reinsurance matters, it is difficult to see how the ceding insurer who conducts his direct insurance transactions in national currency is going to accept to reinsure in a unit of account which is unstable and difficult to handle, when it is so simple for him to reinsure in his national currency.

Above all, their arguments are untenable because the use of a basket of currencies will not always make it possible to obviate the foreign exchange risk. It will do so only when the two currencies concerned diverge from the value of the basket: in this case, the foreign exchange loss (or profit) is actually shared between both parties. On the other hand, when both currencies rise or fall in value simultaneously with respect to the basket, the fate of the two parties to the contract differs : one will make a profit and the other will undergo a greater loss.

This can be demonstrated with the help of a very simple example.

Let us consider the B-Unit, which is a combination of Pounds Sterling, Deutsche Marks, U.S. Dollars, French Francs and Swiss Francs in equal proportions.

The value of the B-Unit was fixed at :

1 B.U. $=£ 1 .-+$ DM $6 .-+\$ 2.40+$ F.F. $11.50+$ S.F. 7.- ;

i.e.

1 B.U. $=£ 5 .-=\mathrm{DM} 30 .-$ at the foreign exchange rate prevailing when the B-Unit was created in 1974.

Let us suppose that during the period $t$ (period when the B-Unit was created), a British importer runs a foreign exchange risk on the DM tied to the existence of a commercial debt of DM 30.- payable on $t+1$.

Two main cases are possible.

If the DM rises, while the pound sterling falls, with respect to the B.U., the importer will sustain a foreign exchange loss shown by the distance (1) in the figure below.

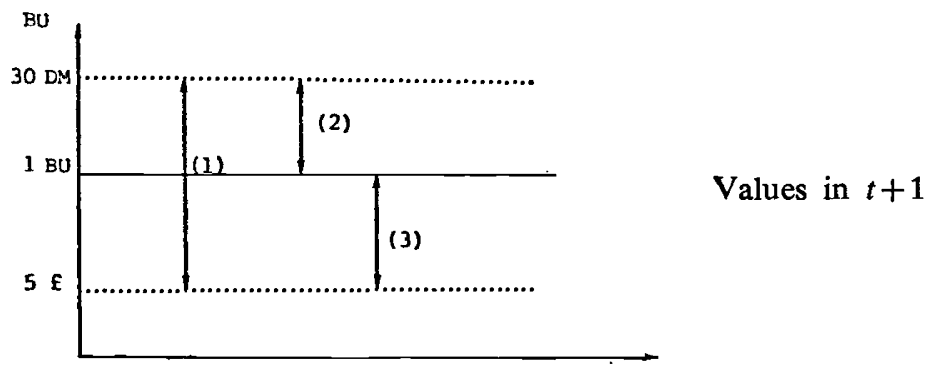


In this case, the payment in B.U. would cause the foreign exchange loss to be shared between exporter and importer in the following proportions : the distance (2) in the figure for the former and the distance (3) for the latter. The exporter would receive one B.U. which represents in $t+1$ a value lower than that of the DM 30.debt recorded in $t$. The importer would have to pay one B.U., i.e. an amount greater than the value of his initial debt ( $£$ 5.- ).

If the D.M. and the $£$ both rise in value with respect to the B.U., with a higher percentage increase for the DM, the importer's loss is limited to the distance (4) in the following figure.

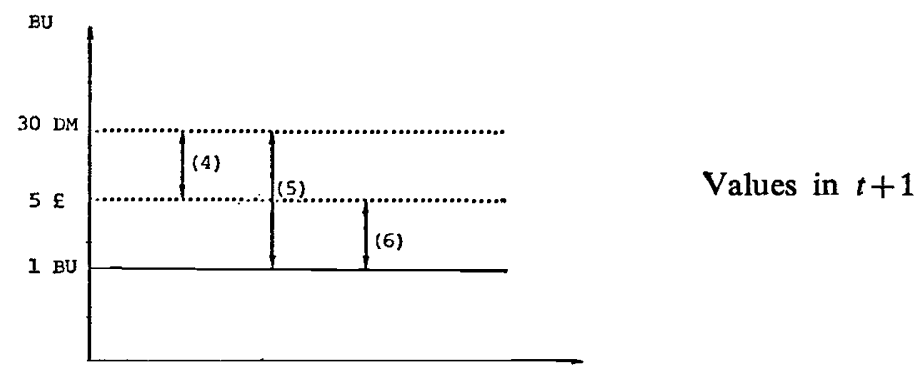

In this case, however, payment in B.U. would produce an asymmetrical result : the loss of an amount (5) for the exporter and a foreign exchange profit in an amount (6) for the importer.

In the circumstances, it is no longer a matter for surprise that foreign currency baskets should have so little success as currencies of payment in international trade. Their use would make it necessary to introduce clauses on the sharing of foreign exchange profits and losses in commercial contracts; these clauses would complicate further a system which is already sufficiently complex.

In any case, it is apparent that the drawbacks of the proposed system would greatly outweigh its advantages if it were to be introduced into the reinsurance business. As a procedure for reducing foreign exchange risk, the use of a basket of currencies is in no event preferable to the traditional procedures.

This being said, the question remains to be examined of determining the rule of conduct to be observed for the use of these traditional procedures.

\section{Guidelines for managing foreign exchange risk in a reinsurance company}

The rule of conduct which is most frequently advocated by reinsurers in matters of foreign exchange risk management is that of congruence. This rule has indeed many advantages, but it also has a number of major drawbacks which justify the consideration of an alternative solution, namely the diversification of foreign exchange exposures.

\subsection{Congruence}

Congruence is achieved when all the foreign exchange exposures are nil. In order to achieve this congruence, it is recommended that the reinsurer should practice a 
policy of financial investments such that, for each currency, his assets will cover exactly his liabilities.

In this manner, he will renounce to foreign exchange profits but in return will almost completely eliminate foreign exchange losses 18 (Jannot [1975]).

Apart from this advantage, the rule of congruence presents three other positive aspects :

- Firstly, it is not very costly to implement since the normal conduct of reinsurance business achieves it, at least in part. This is because the practice of making technical deposits compels the reinsurer to maintain in the currency of acceptance all assets invested as technical reserves. The effort to eliminate foreign exchange exposures will then have to apply only to the representation of those reserves of which he is free to dispose at will : technical reserves of facultative and nonproportional reinsurance treaties, reserves for outstanding claims under certain proportional reinsurance treaties, equalization funds and untied reserves held by the company, i.e. those held in excess of its actual liabilities.

- Second, in a floating currency system, in which the banks allow themselves a substantial margin in their foreign exchange operations with their customers, congruence reduces transaction costs (Jannot [1975, p. 37]).

- Lastly, it enables the reinsurers to create a favourable image with the authorities and the public because the fact of renouncing to foreign exchange profits exonerates them from the suspicion of speculation.

Unfortunately, this rule encounters very serious difficulties in practice. First of all, it is ill-suited to the conditions prevailing in certain financial markets. It fonctions adequately when applied to the currencies of developed countries which have a wide range of financial instruments actively traded in broadly-based markets. It is unsuitable in all other cases because it then exposes the insurer to a risk of capital loss whenever he has to sell out his assets hastily in order to settle large claims ${ }^{19}$.

Above all, the rule fails on the problem of reinsurance liabilities (Bonnasse [1974], Grossman [1977a] and Sonnenholzner [1975]). Since the reinsurer has never an accurate knowledge of the extent of his liabilities, his foreign exchange exposure is unknown to him and he therefore does not know whether congruence is achieved or not. The

18 It should be noted that congruence does not eliminate altogether the foreign exchange risk in so far as there remain at least risks of distortion of results and perhaps also risks connected with reinsurance in the currency of a third country.

19 In the same vein, certain reinsurers state that they avoid making financial investments in those countries where they run an important earthquake risk (Mexico, Japan, etc.) because the materialization of the risk would probably lead to the loss of the assets intended precisely to cover that same risk (see Jannai $[1979$, p. 20]).

Some reinsurers also point out that the regulations in force in certain countries make it impossible to follow a policy of congruence because these regulations oblige them to hold an amount in the foreign currency concerned representing over $100 \%$ of the value of the liabilities actually accepted. It should, however, be pointed out that a financial investments policy is not the only road leading to congruence : if the reinsurer happens to be long on a particular currency, he can easily eliminate this exposure by means of hedging operations in the spot or in the forward market. 
only risk which he can manage in accordance with the principle of congruence is the accounting risk, because the accounting value of the liabilities is a given data and it is therefore sufficient, in order to achieve congruence, to hedge systematically the opening balances. As far as the economic risk is concerned, he can only tend towards congruence and this on the basis of a subjective estimate of his liabilities (Jannot [1975, p. 17]). However, this does not prevent the emergence of foreign exchange losses if he has overestimated (or underestimated) his liabilities in a currency which is falling (or rising) in value.

In the circumstances, the arguments in favour of congruence lose much of their attractiveness. The adoption of this rule of conduct presupposes the setting up of a reliable system for the evaluation of liabilities. In the absence of such a system it does not seem very wise to give up the benefit of foreign exchange profits if this is not balanced by an elimination of the possible losses. Moreover, although most reinsurers advocate the observance of this rule, they are well aware of the fact that it cannot be strictly followed in practice (see Jannai [1979, p. 22]). This is why they often allow themselves a safety margin. In other words, for a given foreign exchange exposure, they try to compensate the foreign exchange losses on certain currencies by means of the profits on others. This comes close to another rule of conduct, namely that of the diversification of the foreign exchange risk.

\subsection{The diversification of foreign exchange exposures}

In matters of foreign exchange risk, the elimination of the risk does not necessarily constitue an optimal goal. For the foreign exchange risk is not a pure risk; it is a speculative risk. Accordingly, the market forces operates so as to remunerate the acceptance of a certain risk by the operators : in an efficient foreign exchange market, the parities for the various currencies are established so as to offer a risk premium that is proportional to the risk resulting from a diversified foreign exchange exposure (see Grauer-Litzenberger-Stehle [1976] and Roll and Solnik [1978]).

Moreover, the risk involved in holding a currency cannot be evaluated independently from the fluctuations in the parities for other currencies. There are positive and negative correlations between these various fluctuations and this makes possible a considerable reduction of the risk arising from a combination of foreign exchange exposures by comparison with the sum of the risks of individual exposures. For example, a positive exposure on the dollar can be offset by a negative exposure on a currency the fluctuations of which are strongly correlated to those of the dollar (e.g. the Canadian dollar or one of the currencies which maintain a fixed parity against the dollar). Similarly, it is obvious that a United States company which is both long on Deutsche Marks and short on Swiss francs does not run the same risk as another United States company which is either only long in DM or only short on SF.

From the foregoing, it is clear that a policy of diversification of foreign exchange exposures is capable both of reducing the overall risk and of producing a stable profit, in proportion to the amount of risk accepted. In contrast with the rule of congruence, this implies a change in the objective pursued : it is no longer a case of eliminating the risk at all costs or the illusory quest for certainty but - in accordance 
with the theory of choices in uncertainty - one of selecting a pair " expected returnrisk" producing a maximum of expected utility subject to specific constraints. ${ }^{20}$

The policy of diversification requires first of all the selection of an optimal combination of foreign exchange exposures and second, the implementation of procedures which make it possible to achieve this combination.

If certain conditions regarding the statistical distribution of foreign exchange rates or the reinsurer's utility function are fulfilled, it is possible to complete the first stage by using as a basis the mean variance model of the theory of portfolio selection (see Kahane [1979], Lietaer [1971] and Loubergé [1979]).

As for the second stage, it is necessarily imperfect because any attempt to arrive at precise figures for foreign exchange exposures will be thwarted by the inaccuracy of the evaluation of liabilities 21 . Nevertheless, this disadvantage is not as decisive here as it is for the rule of congruence because the return on a policy of diversification constitutes anyway a random variable.

In practice, however, the implementation of a policy of diversification comes up against the existing obstacles to capital movements. Some of these obstacles are specific to reinsurance, others are of a more general nature.

The practice of requiring technical deposits undoubtedly constitutes a major obstacle to any strategy of diversification : since a considerable part of the reinsurer's assets are blocked in a deposit account in favour of the ceding insurers, he cannot dispose of them at will to meet the needs of his foreign exchange policy. He is not entirely helpless, of course, since he can manoeuvre with those reserves which are not subject to the deposit requirement and also with the various procedures for reducing and transferring the foreign exchange risk, but his leeway is considerably less than it would be if the requirement of technical deposits did not exist.

Nevertheless, the problem could be resolved very advantageously from the standpoint not only of the management policy of foreign exchange risk, but also of the overall financial policy of reinsurers - if the latter were to succeed in obtaining the extension of the system of "letters of credit" which is at present practiced in the United States. In that country, reinsurers are not required to deposit their technical reserves with the ceding insurers. Instead, they furnish to the latter a letter of guarantee issued by a first-class banking institution (Howard [1975]). Thus, in return for a commission paid to the bank, a reinsurer is free to dispose of the amounts corresponding to the reserves and to invest them either in the Eurocurrencies market

20 It should be noted that the congruence formula is not ruled out by a policy of diversification of foreign exchange exposures but that it becomes a particular case (a corner solution) among a multitude of other feasible solutions. It may sometimes constitute an optimal solution but this is not always necessarily so: it depends on the "price" of the foreign exchange risk in a diversified portfolio and on the reinsurer's attitude towards foreign exchange risk.

21 If the liabilities in dollars finally turn out to be less than expected, the share alloted to the dollar in the reinsurance portfolio will in fact prove higher than it would have been in an optimal portfolio. 
or directly in a foreign financial market through the correspondent of the bank delivering the letter of credit. This system accordingly makes both for a better remuneration of the technical deposits (it is common knowledge that the interest on cash deposits is very low) and for a more flexible policy of foreign exchange risk management. The extension of this system to other countries is thus certainly desirable.

The restrictions of a more general nature result from the existing controls on international capital movements. Reinsurance, as an international activity, has always been affected by restrictions on international exchanges. The difficulties faced by reinsurers in this regard have been all the greater because their activities are not known to the public and because the authorities in charge of the control of relations with foreign countries get easily lost in the maze of reinsurance balances, portfolio movements, cash accounts, securities accounts, etc. ${ }^{22}$ The fact that reinsurance transfers relate at the same time to payments of premiums and claims, to factors income and to short-term capital movements, does not help to make things any clearer, apart from the fact that these transfers often cover the results of a number of reinsurance treaties which partly add up and partly cancel one another out. In a great many cases, reinsurers have therefore been forced to approach the authorities, asking to benefit from a special treatment and to obtain the three freedoms which they consider necessary to the proper functioning of their operations and which are often indiscriminately affected by control measures : freedom of transaction, freedom of transfer and freedom of investment (Jannot [1975, pp. 4-5]).

After the introduction of severe exchange controls during the post-war period and the return to freedom achieved by the OEEC liberalization code (see Schönenberger [1956]), controls on capital movements developed towards the end of the sixties with the object of protecting against all-comers a pattern of unrealistic parities. Reinsurers were all the more affected that these controls were hastily introduced and were provisional in character. It was difficult to obtain a dispensation from these regulations.

The setting up of dual exchange markets thus constituted a step backwards by comparison with the pre-existing situation. In France, the various elements of the reinsurance balance had to be dissociated: the interest on deposit accounts and the operations on securities were channelled through the financial market, whereas the other elements of that balance were channelled through the commercial market. Not long ago, the measures to restrain the inward flow of capital (negative interest, prohibition of investment by non-residents, etc.) in Switzerland have created problems for reinsurers, who sought either to apply the rule of congruence (Jannot [1975, p. 17-20]), or to implement a policy of diversification of foreign exchange exposures; this was all the more so since the countries which resorted to these measures are countries with a liberal tradition where the practice of requiring technical deposits is not very common.

22 Schönenberger [1956, p. 65] writes for example: "Für die ungenügende Beachtung, die den zwischenstaatlichen Rückversicherungszahlungen in den Devisenbewirtschaftungsländern zukam, war auch die Tatsache entscheidend, dass die Rückversicherung in weiten Kreisen nur gerade dem Namen nach bekannt ist. Dass es dann bei der Kompliziertheit des Gegenstandes oftmals schwer fiel, bei den zuständigen Amtstellen das nötige Verständnis für die besonderen und vielgestaltigen Transferbedürfnisse der Rückversicherung zu wecken, leuchtet ohne weiteres ein". 
In order to offset the adverse effects of these measures, the reinsurers have argued convincingly with the central banks of the countries concerned (Germany, Netherlands and Switzerland). They have received a guarantee of automatic dispensation from controls provided that the authorities of the countries to which they belong guarantee reciprocity of treatment.

In this way, the constraints of a policy of congruence are for the most part removed. On the other hand, there remain numerous constraints to a policy of diversification of foreign exchange exposures, either because the outward movement of capital is hindered, or because the reinsurers are not allowed to increase their holdings of a particular currency faster than the corresponding liabilities. The existence of such constraints reduce the relative advantages of a policy of diversification over one of congruence.

\section{Conclusion}

The present study has served to review the major problems faced by reinsurers as a result of fluctuating exchange rates. Here is a list of the main conclusions that can be drawn from it :

(a) The peculiar character of the reinsurance trade creates foreign exchange difficulties for the reinsurers which are not experienced (or at least, not to the same extent) by other branches of economic activity. Reinsurers cannot identify their foreign exchange exposure, not only because their liabilities are uncertain, but also because the information provided by the ceding insurers on the changes in these liabilities is generally inadequate.

(b) Notwithstanding all this, most of the procedures for the management of foreign exchange risks used in international finance meet the requirements of the reinsurers ; they include hedging in the futures market which can be used to deflect the overall foreign exchange exposure in a desired direction. On the other hand, billing in national currency, a procedure which is frequently employed by industrial and commercial firms, is not advisable here since it amounts to reinsuring in the currency of a third country.

(c) The system of reinsuring in the currency of a third country results in distortion of technical results and in gain or loss in the exchange, not only for the ceding insurer but also for the reinsurer or the retrocessionnaire. It is for this reason that all the parties concerned should find it advantageous to conclude reinsurance treaties expressed in the original currency of the direct insurance transactions to which they relate.

(d) Similarly, resort to the system of currency baskets cannot be regarded as a genuine solution of the foreign exchange problems faced by reinsurers. On the contrary, since it involves the same drawbacks as the system of reinsurance in the currency of a third country, and since it results, in certain cases, in an unequal treatment of the parties to the reinsurance treaty, the use of this procedure can only make the problems worse.

(e) The rule of congruence, so insistently advocated by some reinsurers, cannot be applied in practice because of the difficulty of measuring the reinsurer's liabilities. 
Moreover, this rule is sub-optimal since the complete elimination of foreign exchange risk is not necessarily the best solution. Mearing in mind the remuneration of risk in the foreign exchange market, and the correlations between foreign exchange parities, it seems more advisable to apply instead the rule of diversification of foreign exchange exposures, linked to the principle of expected utility maximisation. One is thus led to justify the theoretical studies which have analysed the foreign exchange problems of reinsurers by means of models for the selection of financial portfolios.

\section{REFERENCES}

BONNASSE, P. [1974] : “La réassurance et les problèmes monétaires", La Réassurance, mai-juin 1974, 67-69.

CARTER, R. L. [1979] : Reinsurance, Kluwer, Brentford (Middlesex).

CARTER \& RODRIGUEZ [1976]: International Financial Management, Prenctice Hall, Englewood Cliffs (New Jersey).

COPPOLA, E. [1974] : “Inflation, exchange rate volatility and the insurance industry ", World Insurance Conference, London, March 1974.

ENSOR \& ANTL (Ed.) [1978] : The Management of Foreign Exchange Risk, Euromoney Publications, London.

FAMA, E. F. [1970] : "Efficient capital markets : A review of theory and empirical work", Journal of Finance, 383-417.

GOODMAN, S. H. [1978] : “ No better than the toss of a coin”, Euromoney, December 1978. 75-85.

GRAUER, LITZENBERGER \& STEHLE [1976]: "Sharing rules and equilibrium in an international capital market under uncertainty ", Journal of Financial Economics, 233-256.

GROSSMANN, M. [1974]: “Die Rückversicherung und das 'Floaten' der Währungen”, Versicherungswirtschaft, 1177-1180 and 1256-1259.

GROSSMANN, M. [1977a] : “Währungspolitik des Rückversicherers in neuer Form ?", Versicherungswirtschaft, 621-625.

GROSSMANN, M. [1977b] : Rückversicherung - Eine Einführung, Lang, Bern.

GROSSMANN, M. [1979] : “Internationale Vergleiche bei schwankenden Währungskursen”, Schweizerische Versicherungszeitschrift, 161-167.

HOWARD, E. F. [1975] : “La question des lettres de crédit”, La Réassurance, septembredécembre 1975, 175-179.

JACQUE, L. L. [1978] : Management of Foreign Exchange Risk, Lexington Books, Lexington (Mass.).

JANNAI, S. [1979] : “Matching of assets and liabilities in terms of currency ", NRG Quarterly Letter, March 1979, 16-24.

JANNOT, H. K. [1975]: “Einfluss der Währungsprobleme auf die Rückversicherung", in H. Kalwar (Ed.), Festschrift für Heinz Gehrhardt, Verlag Versicherungswirtschaft, Karlsruhe, 1-25.

KAHANE, Y. [1979] : “ Reinsurers' investment and underwriting portfolios and the exchange rates risk", Geneva Papers on Risk and Insurance, No. 11, 63-67.

KOHLHAGEN, S. W. [1978]: "The behavior of foreign exchange markets: A critical survey of the empirical literature", Monograph Series in Finance and Economics, 1978-3, $1-52$. 
LEPINE, J. [1975] : “International reinsurance", International Insurance Monitor, Vol. XXIX, No. 9, 8-11.

LIETAER, B. A. [1971] : Financial Management of Foreign Exchange, MIT Press, Cambridge (Mass.).

LOUBERGE, H. [1979] : Théorie Financière de l'Assurance et du Risque de Change, doctoral dissertation, University of Geneva.

PRINDL, A. R. [1976] : Foreign Exchange Risk, John Wiley \& Sons, New York.

SCHÖNENBERGER, F. [1956] : Die Lieberalisierung des zwischenstaatlichen Rückversicherungsverkehrs im Rahmen der OECE, doctoral dissertation, St. Gall Graduate School of Economics.

SOLNIK \& ROLL [1978] : Système Monétaire International et Risque de Change, Economica, Paris.

SONNENHOLZNER, F. [1975]: “Les problèmes de l'investissement dans la réassurance internationale", Rendez-Vous de Septembre 1975, Monte-Carlo, 21-44.

VUKAILOVIC, A.D. [1958]: Technisch-ökonomische Betrachtung der Rückversicherung, Verlag Versicherungswirtschaft, Karlsruhe.

WESTBY, D. J. [1977] : "Accounting in convertible currency", CII Journal, 88-93.

X... [1974] : "Currency affairs", NRG Quarterly Letter, August 1974, 17-28.

X... [1975] : “The problem of currency conversion in the preparation of treaty accounts", NRG Quarterly Letter, August 1975, 22-28. 